\title{
Article \\ An Aerobic Degradation Model for Landfilled Municipal Solid Waste
}

\author{
Diankun Xiao, Yunmin Chen, Wenjie $\mathrm{Xu} *$ (D) and Liangtong Zhan
}

Citation: Xiao, D.; Chen, Y.; Xu, W.; Zhan, L. An Aerobic Degradation Model for Landfilled Municipal Solid Waste. Appl. Sci. 2021, 11, 7557. https://doi.org/10.3390/app11167557

Academic Editor: Rafael

López Núñez

Received: 21 July 2021

Accepted: 13 August 2021

Published: 18 August 2021

Publisher's Note: MDPI stays neutral with regard to jurisdictional claims in published maps and institutional affiliations.

Copyright: (c) 2021 by the authors. Licensee MDPI, Basel, Switzerland. This article is an open access article distributed under the terms and conditions of the Creative Commons Attribution (CC BY) license (https:// creativecommons.org/licenses/by/ $4.0 /)$.
MOE Key Laboratory of Soft Soils and Geoenvironmental Engineering, Zhejiang University, Hangzhou 310058, China; diankunxiao@zju.edu.cn (D.X.); chenyunmin@zju.edu.cn (Y.C.); zhanlt@zju.edu.cn (L.Z.)

* Correspondence: wenjiexu@zju.edu.cn
Abstract: Municipalities output large amounts of solid waste into landfills, but degradation slows during the middle and late stages of treatment. Therefore, accelerating the treatment of degradable substances to achieve rapid stabilization, excavation, screening, and reuse would increase landfill utility and reduce economic costs. This article provides an aerobic degradation model for landfilled municipal solid waste that includes two types of biochemical reactions. Using degradable solid-phase organic matter and ammonia nitrogen as limiting substrates, an equation describing degradation over time was obtained. Both aerobic organic matter hydrolysis and the synchronous nitrification and denitrification reaction followed a kinetic, first-order equation. The influences of temperature, water content, oxygen concentration, and carbon to nitrogen ratio on the kinetic reactions were considered. Similarly, the exothermic reaction characteristics were considered. The model was applied to two previously conducted experiments. The results showed that the model can accurately reflect the degradation laws of various substances under aerobic degradation conditions. SDC and ammonia nitrogen were rapidly degraded and reached very low levels in a short time under aerobic conditions. This indicated that aeration has a significant effect on the degradation of aged waste, which can be used in the accelerated stabilization of aged landfills in the future.

Keywords: municipal solid waste; aerobic degradation; stoichiometric equations; dynamic model

\section{Introduction}

Municipalities produce a large amount of solid waste, and landfills are an important disposal method. Landfill disposal utilizes anaerobic microbial degradation, which proceeds quickly initially but slows during the middle and late stages when only cellulose, lignin, and other refractory substances remain, making it difficult to reach reuse standards. With long processing times, economic costs increase, heavy metals pollute [1], and valuable landfill storage resources are occupied for longer periods of time. This is especially important considering that urban space is limited, and land use is tight. It is therefore important to achieve the state of mineralized waste as quickly as possible by accelerating and stabilizing landfilled municipal solid waste (MSW), excavation, and screening for resource utilization, thereby freeing space to be re-filled with waste, and realize sustainable landfill practices [1-10]. Thermochemical decomposition is an effective method to treat organic matter disposal [10]. On site, ventilation and oxygen supply are commonly implemented landfill acceleration stabilization measures [11-14]. Therefore, in this study, a model of biochemical waste degradation is introduced under the pre-condition of having ventilation and an oxygen supply.

With regard to the underlying theory, first-order [15-21] or Monod-type equations [22-26] are usually used to calculate respiration rates as a function of the organic waste degradation rate. The main factors that control the degradation process include temperature, moisture content, $\mathrm{pH}$, aeration rate, $\mathrm{C} / \mathrm{N}$ ratio, particle size, and nutrient content [27-31]. However, 
it is inappropriate to include too many parameters in models, so it is important to select those that are most influential.

Organic matter decomposition and aerobic stabilization of aged municipal landfills has been previously investigated in depth [32-34]. Some studies investigated the conversion of carbon and nitrogen compounds in the aerated solid waste, leachates, and gas phases under changing conditions [35-37]. These demonstrated that aeration clearly reduced emissions and stabilized the organic matter and resulted in an increased amount of nitrogen being removed.

A method to establish biochemical stoichiometric equations that includes microorganisms as a medium has been previously proposed [38]. This method requires three kinds of semi-reactants: electron donors such as sugar, fats, proteins, and organic acids; electron acceptors including oxygen, nitrate, nitrogen, and carbon dioxide; and cells for synthesis. There are mainly three types of biochemical reactions that occur during aerobic waste degradation [39]: aerobic hydrolysis of organic matter, which removes organic pollutants by consuming oxygen; aerobic nitration reactions, which consumes mainly oxygen to convert ammonia nitrogen to nitrate nitrogen; and denitrification, which converts nitrate nitrogen to nitrogen while consuming large amounts of organic matter. However, previous studies investigating MSW degradation did not consider all the types of biochemical reactions when examining degradation in landfills.

In order to solve the problem of high residual degradable organic matter and ammonia nitrogen in aged MSW, a set of biochemical reaction equations of MSW aerobic degradation was established based on electron flow and mass conservation, and the mass change relationship of each substance was established in the form of a matrix, and the release of heat was considered. The first-order kinetic equation was used to describe the time-dependent process of each limited substrate, and the effects of temperature, moisture content, oxygen concentration, initial carbon nitrogen ratio, and other factors were considered so as to establish a complete set of a dynamic model that can reflect the changes of various substances of municipal solid waste under aerobic degradation conditions. It can provide the most basic biochemical parameters for landfill settlement, leachate generation, landfill gas release, etc., which can be further combined with the multi-coupling model in the future to provide a theoretical basis for the stability assessment and operation of landfills.

\section{Stoichiometric Equations}

The stoichiometric equations were built based on the principles of conservation of electron charge and mass. Assuming that organic hydrolysis is the rate-limiting step, various organic matter sources were set as electron donors, and $\mathrm{O}_{2}$ was as used as the electron acceptor. Using these conditions, the stoichiometric equations for the two types of aerobic biochemical degradation reactions were established.

\subsection{Aerobic Hydrolysis of Organics}

The biodegradable organics in MSW mainly include sugars, celluloses, lignins, proteins, and fats. Celluloses, sugars, proteins, fats, and methane bacteria are used as limiting substrates to establish anaerobic biodegradation models [40,41]. Here, with reference to their research methods, rapid degradation cellulose (abbreviated hereafter as RDC: $\left.\mathrm{C}_{6} \mathrm{H}_{10} \mathrm{O}_{5}\right)$, slow degradation cellulose (SDC: $\left.\mathrm{C}_{6} \mathrm{H}_{10} \mathrm{O}_{5}\right)$, total sugar $\left(\mathrm{C}_{6} \mathrm{H}_{10} \mathrm{O}_{5}\right)$, fat $\left(\mathrm{C}_{55} \mathrm{H}_{104} \mathrm{O}_{6}\right)$, protein $\left(\mathrm{C}_{46} \mathrm{H}_{77} \mathrm{O}_{17} \mathrm{~N}_{12} \mathrm{~S}\right)$, ammonia $\left(\mathrm{NH}_{3}\right)$, and microorganisms (referring to aerobic bacteria, nitrifying bacteria, and denitrifying bacteria) were adjusted to be limiting substrates.

The aerobic hydrolysis of organic matter refers to the redox reaction between organic matter and oxygen. Microorganisms that undergo aerobic hydrolysis can be represented by $\mathrm{C}_{5} \mathrm{H}_{7} \mathrm{O}_{2} \mathrm{~N}[42,43]$, a relationship that has since been widely used by scholars and which will be used here.

Regarding the heat release, degraded glucose, fat, and protein release heat amounting to $16.73 \mathrm{~kJ}, 37.64 \mathrm{~kJ}$, and $16.73 \mathrm{~kJ}$ per gram, respectively [44]. From this, the amount of heat 
generated per mole of organic matter can be determined, and the stoichiometric formulae are written as follows:

RDC oxidation equation:

$$
\mathrm{C}_{6} \mathrm{H}_{10} \mathrm{O}_{5}+4 \mathrm{O}_{2}+\frac{2}{5} \mathrm{NH}_{3}=\frac{2}{5} \mathrm{C}_{5} \mathrm{H}_{7} \mathrm{O}_{2} \mathrm{~N}+4 \mathrm{CO}_{2}+\frac{21}{5} \mathrm{H}_{2} \mathrm{O}+\Delta \mathrm{Q}_{1}
$$

SDC oxidation reaction equation:

$$
\mathrm{C}_{6} \mathrm{H}_{10} \mathrm{O}_{5}+4 \mathrm{O}_{2}+\frac{2}{5} \mathrm{NH}_{3}=\frac{2}{5} \mathrm{C}_{5} \mathrm{H}_{7} \mathrm{O}_{2} \mathrm{~N}+4 \mathrm{CO}_{2}+\frac{21}{5} \mathrm{H}_{2} \mathrm{O}+\Delta \mathrm{Q}_{2}
$$

Total sugar oxidation reaction equation:

$$
\mathrm{C}_{6} \mathrm{H}_{10} \mathrm{O}_{5}+4 \mathrm{O}_{2}+\frac{2}{5} \mathrm{NH}_{3}=\frac{2}{5} \mathrm{C}_{5} \mathrm{H}_{7} \mathrm{O}_{2} \mathrm{~N}+4 \mathrm{CO}_{2}+\frac{21}{5} \mathrm{H}_{2} \mathrm{O}+\Delta \mathrm{Q}_{3}
$$

Fat oxidation reaction equation:

$$
\mathrm{C}_{55} \mathrm{H}_{104} \mathrm{O}_{6}+58 \mathrm{O}_{2}+4 \mathrm{NH}_{3}=4 \mathrm{C}_{5} \mathrm{H}_{7} \mathrm{O}_{2} \mathrm{~N}+35 \mathrm{CO}_{2}+44 \mathrm{H}_{2} \mathrm{O}+\Delta \mathrm{Q}_{4}
$$

Protein oxidation reaction equation:

$$
\mathrm{C}_{46} \mathrm{H}_{77} \mathrm{O}_{17} \mathrm{~N}_{12} \mathrm{~S}+34.25 \mathrm{O}_{2}=3 \mathrm{C}_{5} \mathrm{H}_{7} \mathrm{O}_{2} \mathrm{~N}+31 \mathrm{CO}_{2}+9 \mathrm{NH}_{3}+\mathrm{H}_{2} \mathrm{SO}_{4}+13.5 \mathrm{H}_{2} \mathrm{O}+\Delta \mathrm{Q}_{5}
$$

where $\Delta Q$ represents the heat released by the biochemical reactions of various organic substances. The heat released by RDC, SDC, total sugar, fat, and protein were $2575.8 \mathrm{~kJ} / \mathrm{mol}$, $2575.8 \mathrm{~kJ} / \mathrm{mol}, 2575.8 \mathrm{~kJ} / \mathrm{mol}, 30,616 \mathrm{~kJ} / \mathrm{mol}$, and $20,698.8 \mathrm{~kJ} / \mathrm{mol}$, respectively.

\subsection{Synchronous Nitrification and Denitrification}

Under oxygen rich conditions, autotrophic bacteria use oxygen to oxidize ammonia nitrogen into nitrite nitrogen and nitrate nitrogen, which is called aerobic nitrification. Similarly, nitrite nitrogen and nitrate nitrogen are reduced to nitrogen by denitrifying bacteria under anoxic conditions, which is called anaerobic denitrification. Normally, waste quickly becomes anaerobic and remains that way for a long period of time, which results in the accumulation of a large amount of ammonia nitrogen. When oxygen is supplied, microbes can undertake aerobic nitrification and anaerobic denitrification to remove ammonia nitrogen. For our purposes, we simplified the process by omitting the complicated intermediate products and only included the initial and final products in the chemical formula, hereafter referred to as the synchronous nitrification and denitrification reaction (SND). The exothermic heat produced by the SND is far less than that produced by the organic matter hydrolysis reaction, so it is not considered here.

$$
\mathrm{NH}_{3}+0.75 \mathrm{O}_{2}=0.5 \mathrm{~N}_{2}+1.5 \mathrm{H}_{2} \mathrm{O}
$$

When the organic matter is exhausted, the microbes that use it as a food source die. Under aerobic conditions, deceased microorganisms decompose into small molecules, carbon dioxide, ammonia, and water. The heat produced during microbial decay is far less than that produced by the organic matter hydrolysis reaction, so it is not considered here.

$$
\mathrm{C}_{5} \mathrm{H}_{7} \mathrm{O}_{2} \mathrm{~N}+5 \mathrm{O}_{2}=5 \mathrm{CO}_{2}+\mathrm{NH}_{3}+2 \mathrm{H}_{2} \mathrm{O}
$$




\section{Dynamic Model}

\subsection{Kinetics of Hydrolysis}

Following the anaerobic model [40], a first-order kinetic model was adopted for the aerobic degradation of organics. When biodegradation reaches equilibrium, the mass balance and the mass change rate of each substance can be described by Equations (8) and (9), respectively:

$$
\begin{gathered}
C_{j, i} \cdot S_{i}=0(i=1,2,3, \ldots, 12 ; j=1,2,3, \ldots, 7) \\
\frac{d S_{i}}{d t}=\alpha_{i} \sum_{j=1}^{7}\left(C_{j, i} R_{j}\right)
\end{gathered}
$$

where $C_{j, i}$ represents the conversion ratio coefficient, which can be calculated from $C=C_{c} \cdot C_{m}$, wherein $C_{\mathrm{c}}$ is the mass conservation equation coefficient matrix (reactants are negative, products are positive, the limiting substrate coefficient is -1 , and if it is not involved in the reaction, it is 0$), C_{\mathrm{m}}$ is the quality coefficient matrix, and $C_{\mathrm{m}}(j, i)$ represents the molar mass ratio of material $i$ to the limiting substrate in the $j$ th chemical reaction; $\alpha_{i}$ is concentration conversion factor of the $i$ th substance (if it is a liquid solute substance, it is $1 / \theta$ and $\theta$ is volumetric moisture content, other materials are 1$)$; and $R_{\mathrm{j}}$ is the reaction rate of the $j$ th group of chemical reactions when reacting independently, which is related to the concentration of reactants, temperature, moisture content, oxygen concentration, carbon to nitrogen ratio, etc.

The above biochemical molecular stoichiometric equations (Equations (1)-(7)) involve a total of 12 substances, including RDC, SDC, total sugars, fats, proteins, microorganisms, ammonia, sulfate radicals, oxygen, carbon dioxide, nitrogen, and water. According to the above 12 substances and 7 reaction formulas, the conversion ratio coefficient $C$ can be written in the form of a matrix.

$$
C=\left[\begin{array}{cccccccccccc}
-1 & 0 & 0 & 0 & 0 & 0.2790 & -0.0420 & 0 & -0.7901 & 1.0864 & 0 & 0.4667 \\
0 & -1 & 0 & 0 & 0 & 0.2790 & -0.0420 & 0 & -0.7901 & 1.0864 & 0 & 0.4667 \\
0 & 0 & -1 & 0 & 0 & 0.2790 & -0.0420 & 0 & -0.7901 & 1.0864 & 0 & 0.4667 \\
0 & 0 & 0 & -1 & 0 & 0.5256 & -0.0791 & 0 & -2.1581 & 1.7907 & 0 & 0.9209 \\
0 & 0 & 0 & 0 & -1 & 0.3079 & 0.1390 & 0.0890 & -0.9955 & 1.2389 & 0 & 0.2207 \\
0 & 0 & 0 & 0 & 0 & 0 & -1 & 0 & -1.4118 & 0 & 0.8235 & 1.5882 \\
0 & 0 & 0 & 0 & 0 & -1 & 0.1504 & 0 & -1.4159 & 1.9469 & 0 & 0.3186
\end{array}\right]
$$

The aerobic hydrolysis reaction rate is related to temperature, water content, oxygen concentration, limiting substrate concentration, etc. [45,46]. It has been shown that the Cardinal Temperature Model with Inflection (CTMI) [46] provided parameters that were more consistent over the composting temperature range, and, more importantly, variability in parameters could be attributed to the microbial processes. Adhikari et al. (2008), Chang and Hsu (2008), Kumar et al. (2010), Li et al. (2012), Xue et al. $(2018,2020)$ cited and applied it well. The limiting substrates aerobic oxidation reaction rates of Equations (1)-(5) can therefore be expressed as

$$
R_{j}=-k_{h j} \cdot f(T) \cdot f\left(C_{\text {water }}\right) \cdot f\left(C_{O 2}\right) \cdot f\left(C_{C / N}\right) \cdot S_{j}
$$

where $k_{h j}$ is the first-order hydrolysis rate constant for aerobic hydrolysis of the $j$ th limiting substrate, $\mathrm{d}^{-1} ; R_{j}$ is the reaction rate of the limiting substrate; $S_{j}$ is the limiting substrate concentration; $f(T)$ is the temperature influence function; $f\left(C_{\text {water }}\right)$ is the water content influence function; $f\left(C_{\mathrm{O} 2}\right)$ is the oxygen content influence function; $f\left(C_{\mathrm{C} / \mathrm{N}}\right)$ is the initial carbon to nitrogen ratio influence function; $C_{w a t e r}$ is the moisture content; and $C_{\mathrm{O} 2}$ is the oxygen volumetric content.

The expression of the temperature influence function was originally proposed by Rosso et al. (1993). Ma (2018) used this temperature expression to build the degradation 
kinetic model and got a good fitting result. The influence factor of temperature can be expressed by Equation (12):

$$
f(T)=\frac{\left(T-T_{\max }\right)\left(T-T_{\min }\right)^{2}}{\left(T_{o p t}-T_{\min }\right)\left[\left(T_{o p t}-T_{\min }\right)\left(T-T_{o p t}\right)-\left(T_{o p t}-T_{\max }\right)\left(T_{o p t}+T_{\min }-2 T\right)\right]}
$$

where $T_{\min }, T_{\text {opt }}, T_{\max }$ represent the minimum, optimal, and maximum temperatures, respectively, which were set at 0,50 , and $65^{\circ} \mathrm{C}$ [23]. When the temperature is less than $10^{\circ} \mathrm{C}$, the temperature influence factor is less than 0.1 ; when the temperature is between 10 and $50{ }^{\circ} \mathrm{C}$, the temperature influence factor increases linearly with the temperature; when the temperature is greater than $50^{\circ} \mathrm{C}$, the temperature influence factor decreases parabolically until it is 0 (Figure 1).

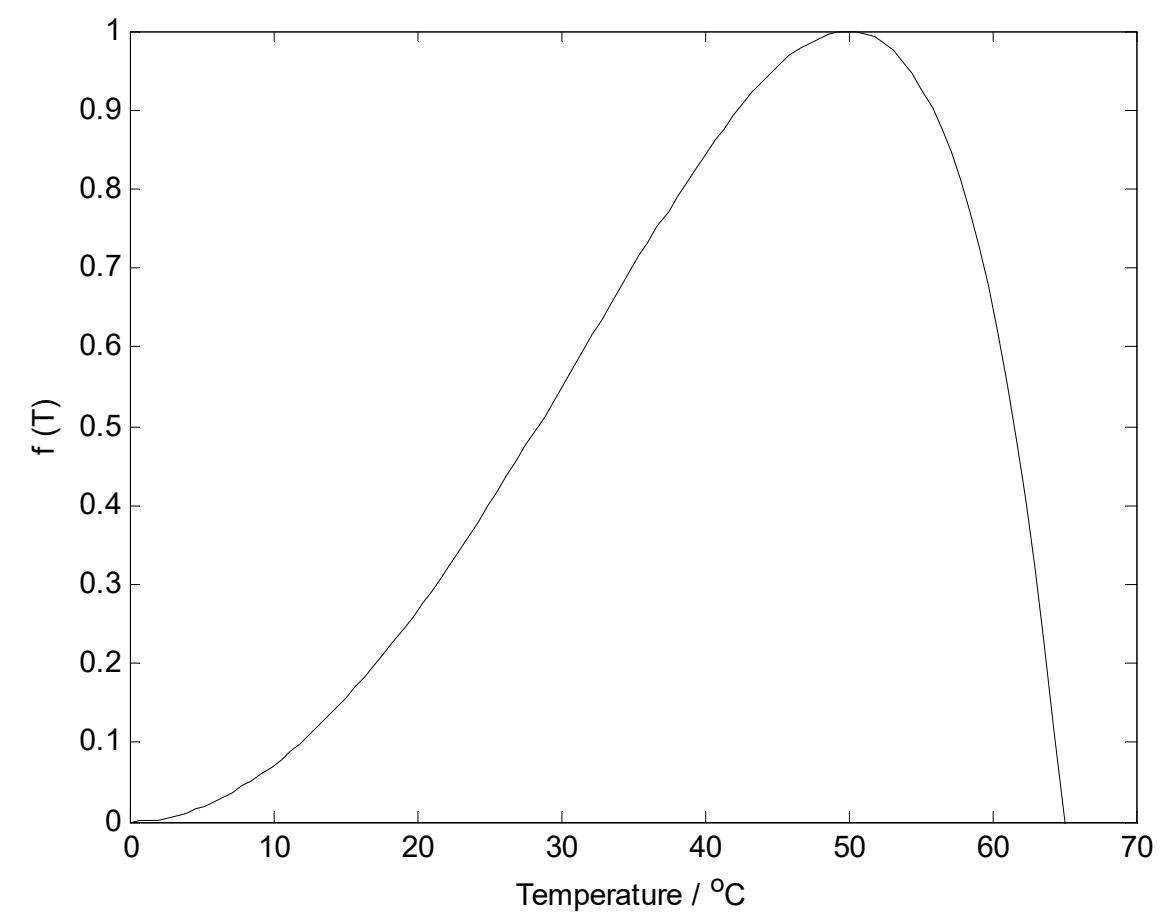

Figure 1. Temperature influence factor changes with temperature.

The effect of moisture content is mainly reflected in the ability of microorganisms to use nutrients and its effect on reducing air-permeable space. Haug (1993) proposed the correction formula of water content on degradation rate. Petric et al. (2015) used it to simulate the compost degradation process, and the results showed that the formula had a good fitting effect on moisture content. The water content is between 0 and 0.3 , and the water content influence factor changes slowly at less than 0.1 ; the water content is between 0.3 and 0.6 , showing a non-linear and rapid growth; and the water content is greater than 0.6 , slowly approaching 1 (Figure 2).

$$
f\left(C_{\text {water }}\right)=\frac{1}{e^{\left(-17.684 C_{\text {water }}+7.0622\right)}+1}
$$




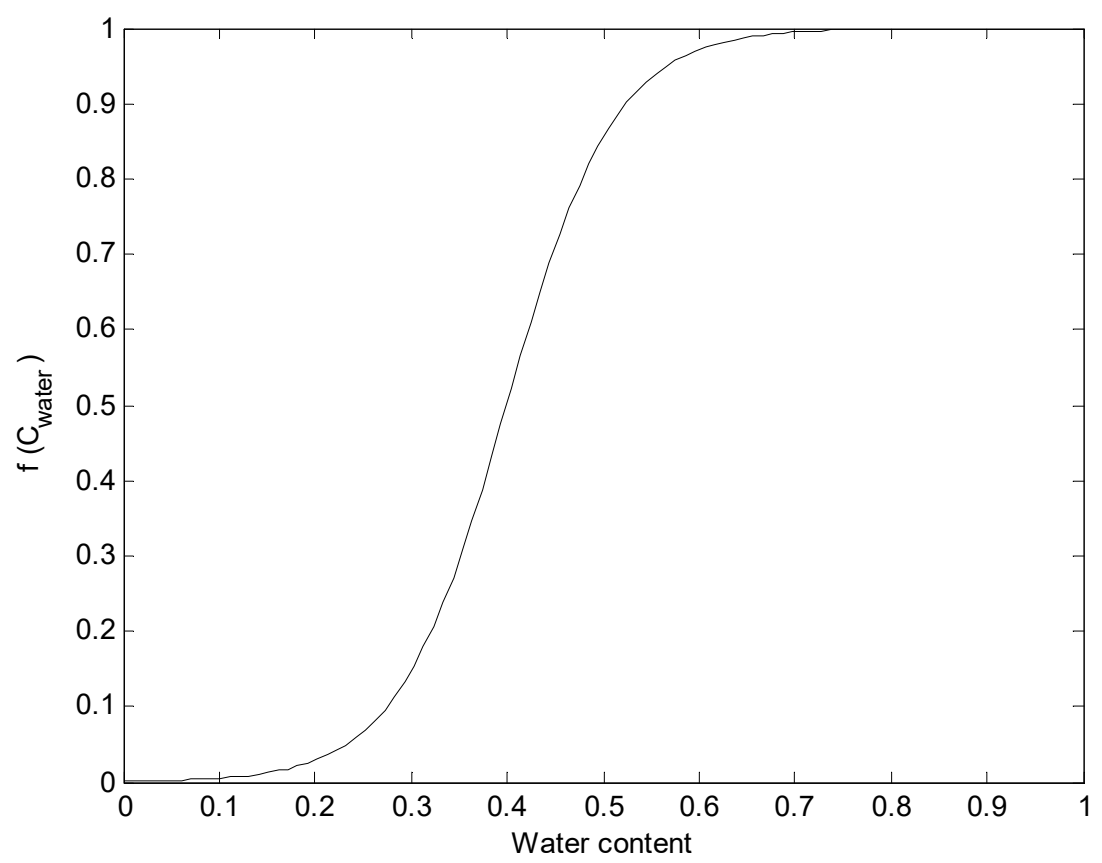

Figure 2. Water content influence factor changes with water content.

Generally, if oxygen in the voids of MSW is more than $5 \%$ of the total volume, the metabolism by aerobic microorganisms is not seriously inhibited. The adjustment of the oxygen content (volume fraction) to the reaction rate was first proposed by Haug (1993) and can be expressed by Equation (14). Higgins (2001) used it to define oxygen uptake reaction kinetics and obtained good fitting results. The oxygen concentration influence factor shows a rapid increase with the oxygen volume fraction at the beginning and then slowly approaches 1 (Figure 3).

$$
f\left(C_{\mathrm{O} 2}\right)=\frac{C_{\mathrm{O} 2}}{C_{\mathrm{O} 2}+2 \%}
$$

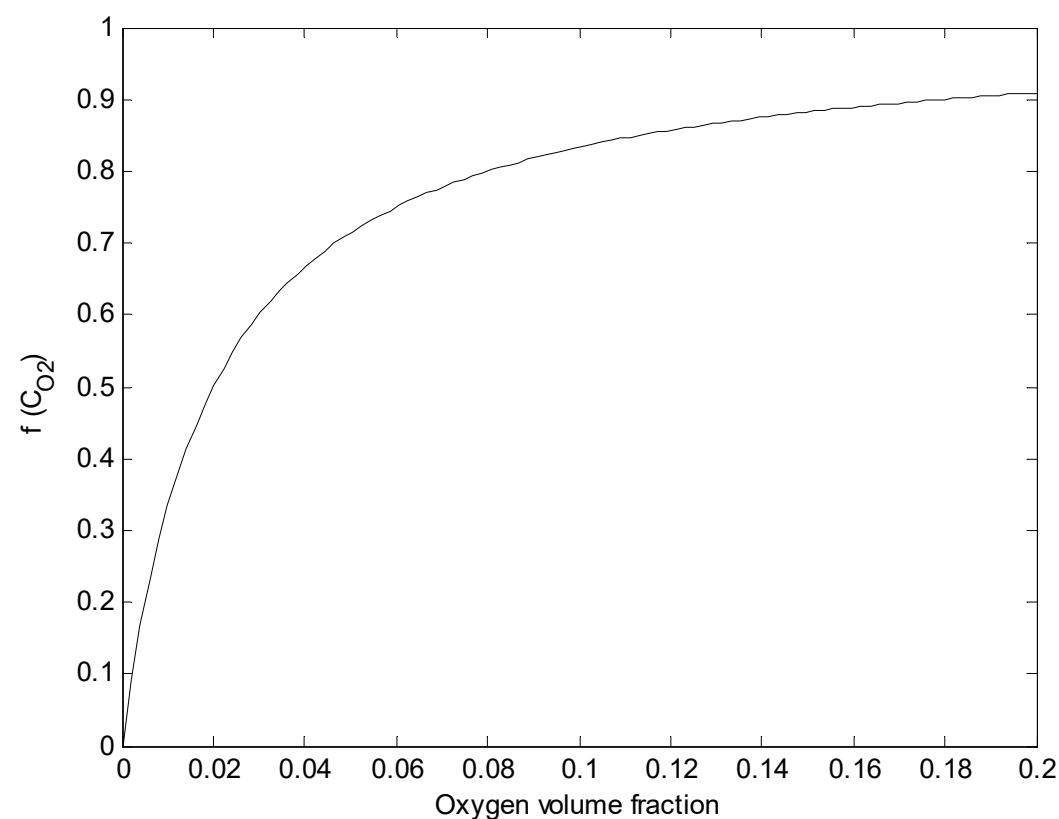

Figure 3. Oxygen concentration influence factor change with oxygen concentration. 
The metabolic processes of microorganisms have different carbon and nitrogen requirements when obtaining energy and synthesizing cell material. Carbon is the primary energy source of microorganisms, while nitrogen is mainly used by microorganisms to synthesize protoplasm for cell production. The higher the carbon-to-nitrogen ratio, the more organic matter that microorganisms can use, the stronger the microbial activity, and the higher the digestion efficiency. However, when the nitrogen source exceeds the optimal range, or the carbon source is insufficient, microbial activity decreases, and the degradation process slows. When the carbon-to-nitrogen ratio is too low, the nitrogen becomes excessive. During the reaction, the amount of nitrogen in the microbial decomposition medium exceeds the requirements to synthesize cells. The excess nitrogen will be released in the form of $\mathrm{NH}_{3}$, which causes nitrogen loss and produces a foul odor. The recommended carbon-nitrogen ratio range for domestic waste processing is 20:1-40:1, and the optimal range is 25:1-30:1 [47]. Here, the Gaussian function was used to fit the experimental data and construct the formula that describes the effect of the initial carbon-nitrogen ratio on the reaction rate. The initial carbon-nitrogen ratio influence factor and initial carbon-nitrogen ratio exhibit normal distribution relationships, reaching a peak when the carbon to nitrogen ratio is 28 (Figure 4 ).

$$
f\left(C_{C / N}\right)=e^{\left.-\left(C_{C / N}-28\right) / 14\right)^{2}}
$$

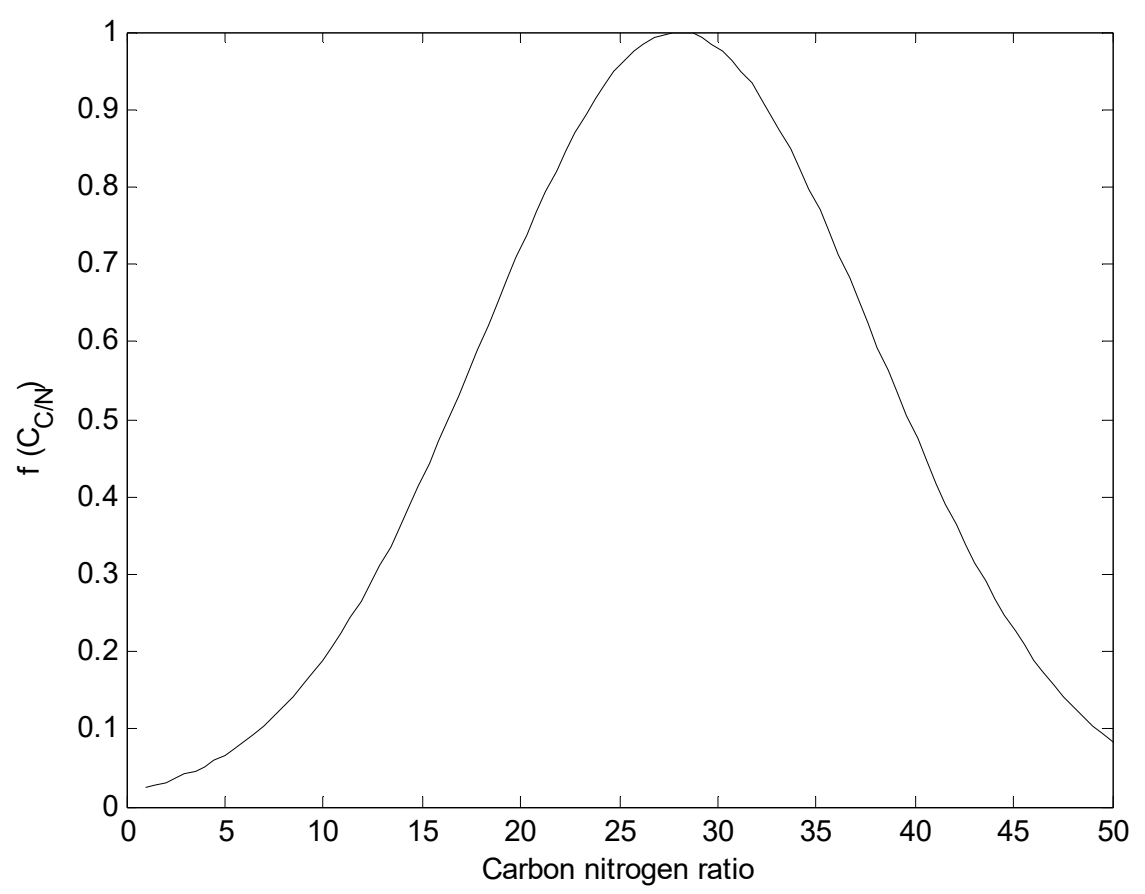

Figure 4. $\mathrm{C} / \mathrm{N}$ ratio influence factor change with $\mathrm{C} / \mathrm{N}$.

\subsection{Kinetics of Synchronous Nitrification and Denitrification}

The synchronous nitrification and denitrification reaction uses the first-order kinetic equation as follows:

$$
R_{6}=\theta k_{N} \cdot f(T) \cdot f\left(C_{\text {water }}\right) \cdot f\left(C_{O 2}\right) \cdot f\left(C_{C / N}\right) \cdot S_{j}
$$

where $k_{N}$ is the first-order kinetic reaction rate constant of synchronous nitrification and denitrification; $\theta$ is the volumetric water content; and other variables are the same as above.

\subsection{Kinetics of Microbial Decay}

A first-order kinetic formula is also used to describe microbial decay, as follows:

$$
R_{7}=\theta K_{d} f_{T d} S_{5}
$$




$$
f_{T d}=\left\{\begin{array}{l}
\exp \left[-\lambda_{d}\left(T-T_{s}\right)^{2}\right]\left(T<T_{s}\right) \\
1\left(T \geq T_{s}\right)
\end{array}\right.
$$

where $f_{T d}$ is the effect function of temperature on the microbial decay rate; $\lambda_{d}$ is the temperature effect parameter with a default value of 0.004 ; and the value of $T s$ is $65^{\circ} \mathrm{C}$.

Since the reaction rate of each process has been defined, the heat generation or consumption can be expressed as

$$
\frac{d Q}{d t}=\sum_{j=1}^{7} \Delta Q_{j} R_{j}
$$

\section{Verification}

In order to test the validity and applicability of the model, we extracted data from two experimental studies for verification $[35,37]$ and used OpenGeoSys open source software and the ZJU calculator for numerical simulation; there is no special optimizer for parameter optimization.

\subsection{Experiment 1}

\subsubsection{Experimental Introduction}

An indoor aerobic degradation study in an old landfill in southeastern Vienna was conducted [35]. The age of the sampled waste was between 8 and 17 years. The physical composition of the sampled waste was $31 \%$ residue, $12 \%$ bulky waste, $25 \%$ commercial waste, $19 \%$ construction waste, and 13\% compost waste. Waste was passed through a $20 \mathrm{~mm}$ sieve, and waste smaller than $20 \mathrm{~mm}$ was used for the experiment. The experimental chambers had diameters of $20 \mathrm{~cm}$ and heights of $65 \mathrm{~cm}$. The experimental temperature was controlled at 35 degrees Celsius. The initial masses of S3 and S6 columns were $14.6 \mathrm{~kg}$ and $15.7 \mathrm{~kg}$, and the densities were $1.25 \mathrm{t} / \mathrm{m}^{3}$ and $1.37 \mathrm{t} / \mathrm{m}^{3}$, respectively. The mass water content of the freshly collected waste was $41.4 \%$. The experiment was carried out for 513 days. The S3 treatment was oxygenated and recharged for all 513 days, while the S6 treatment was oxygenated and recharged for 275 days, with an oxygen concentration twice that of S3, and 243 days were allowed for anaerobic recharge operation. Total organic carbon (TOC), total nitrogen (TN), humic acid, and cellulose were measured at the beginning and end of solid waste samples; the leachate quality was sampled once a week; and the test indexes include chemical oxygen demand, ammonium, and nitrate. Oxygen, carbon dioxide, and methane concentration were measured continuously.

\subsubsection{Model Parameters}

It was assumed that the entire reaction proceeded within a given unit volume of refuse, and the remaining organic matter was mainly SDC. The sum of the SDC in the solid and liquid phases was taken as the initial carbon content; similarly, nitrogen-containing organic matter in solid and liquid phases was taken as the initial ammonia nitrogen content. Due to the sampling and placement of the two-unit columns, the initial total SDC concentrations were $56.0 \mathrm{~kg} / \mathrm{m}^{3}$ and $23.1 \mathrm{~kg} / \mathrm{m}^{3}$, respectively. Similarly, the initial ammonia nitrogen concentrations were $30 \mathrm{~kg} / \mathrm{m}^{3}$ and $22 \mathrm{~kg} / \mathrm{m}^{3}$, respectively. The oxygen volume fraction under the different aeration rates was $10 \%$ and $20 \%$, respectively. The initial carbon-nitrogen ratios were taken as the ratio in the solid phase and were 22 and 18 in treatments S3 and S6, respectively. The values of other reaction rate constants are given in Table 1 [15-21].

Table 1. Biological parameter for simulation.

\begin{tabular}{ccc}
\hline Parameter & Symbol & Value (Day $^{-1}$ ) \\
\hline First order aerobic hydrolysis constant & $k_{h}$ & 0.4 \\
\hline First order SND constant & $k_{N}$ & 1.0 \\
\hline Microbial decay rate constant & $k_{d}$ & 1.0 \\
\hline
\end{tabular}




\subsubsection{Results and Discussion}

In this work, using the constructed model, we compared between monitoring data and simulation results for carbon-containing organic matter and $\mathrm{NH}_{3}$ in the two-unit columns. The SDC was rapidly degraded and decreased to a very low level within the first two months, especially during the first week of oxygen supply. Then the SDC entered an extended period of slow decline. This was mainly due to the rapid biochemical reaction of SDC with oxygen under ventilation, and the SDC was hydrolyzed into small molecular organic matter, which was rapidly reduced in a short time. Between the two treatments, the S6 unit column with higher oxygen concentrations had significantly faster SDC degradation rates (Figure 5).

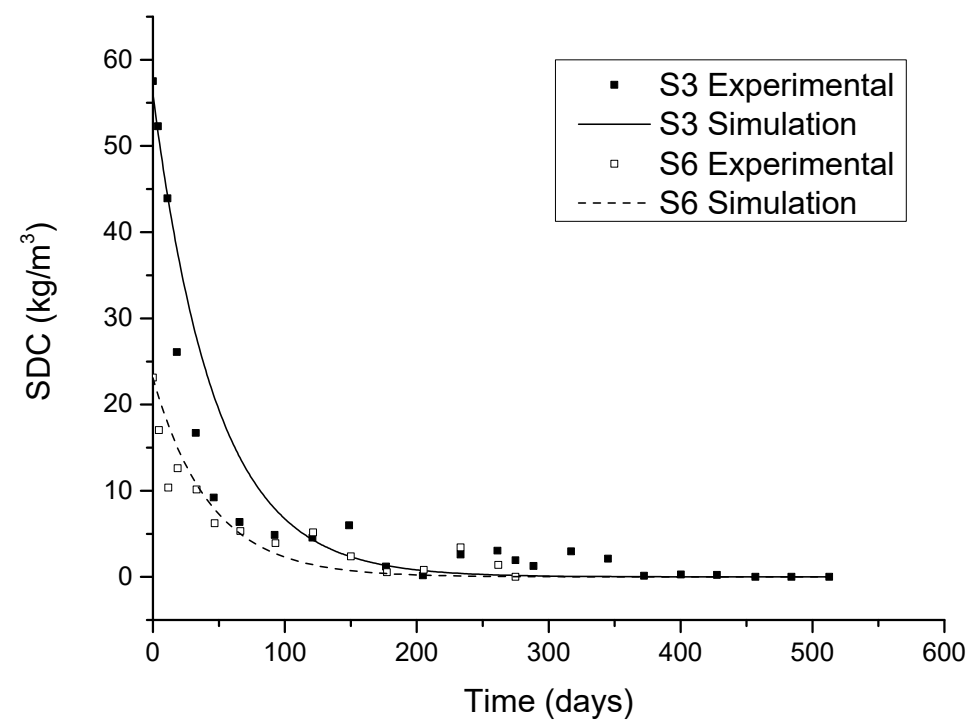

Figure 5. Time profiles of SDC degradation (experimental data cited in [35]).

Ammonia nitrogen concentration rapidly degraded to a very low level within 2 months ( $\sim 60$ days), after which it decreased slowly. Ammonia nitrogen started SND under ventilation and changed into nitrogen. The consumption cycle of ammonia nitrogen was roughly synchronized with SDC. The degradation rate of S6 was obviously faster than that of S3 (Figure 6).

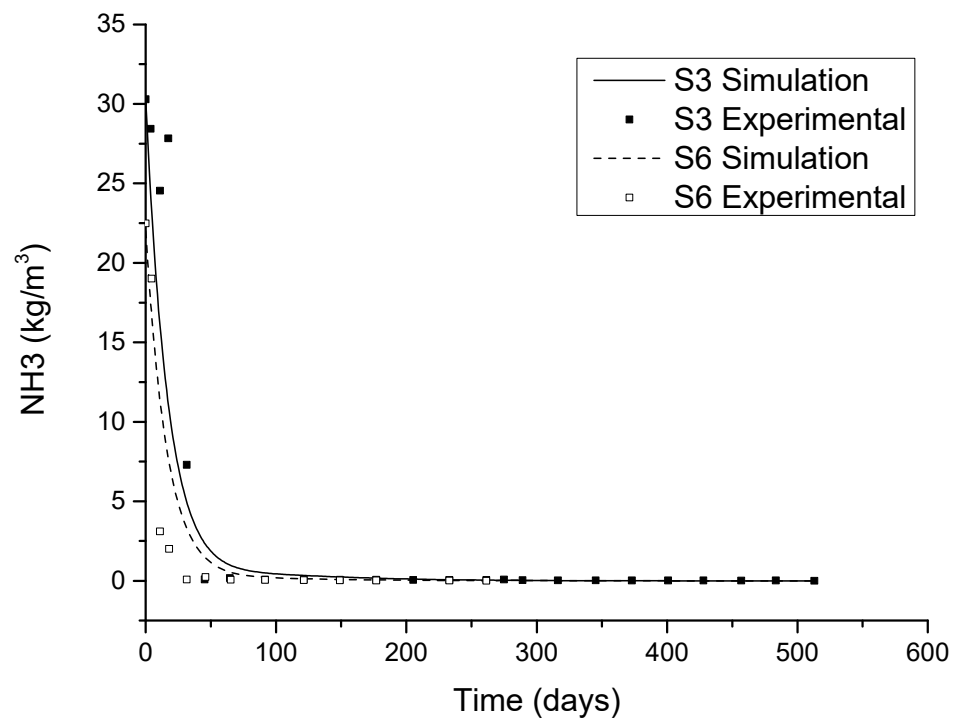

Figure 6. Time profiles of $\mathrm{NH}_{3}$ degradation (experimental data cited in [35]). 


\subsection{Experiment 2}

\subsubsection{Experimental Introduction}

Waste was sampled from the Shanghai Laogang Landfill [37], which was aged 5-8 years and composed of ceramic stone, $28.6 \%$; glass, $6.7 \%$; wood bamboo straw, $6.6 \%$; food waste, $6.0 \%$; and plastic, $4.7 \%$; $43 \%$ of the particles were fine-grained soil less than $5 \mathrm{~mm}$. Waste samples were packed into two pilot scale unit columns (lysimeters), which had diameters of $1 \mathrm{~m}$ and heights of $3 \mathrm{~m}$, and both (A and $\mathrm{B}$ ) were aerobic. The mass water contents of the waste were $40.4 \%$ and $43.0 \%$, respectively. The packing density of both were $1.4 \mathrm{t} / \mathrm{m}^{3}$. The carbon and nitrogen contents at the beginning and end of the solid waste samples were measured. The liquid samples were taken once a week for three months, and the test indexes included TOC and TN. The oxygen and methane contents were measured every $20 \mathrm{~min}$.

\subsubsection{Model Parameters}

The whole process was assumed to take place within the set unit volume. Degradable substances were categorized as SDC. The sum of the SDC in the solid and liquid phases was taken as the initial degradable organic matter and was $10.8 \mathrm{~kg} / \mathrm{m}^{3}$ and $12.0 \mathrm{~kg} / \mathrm{m}^{3}$ in lysimeters $\mathrm{A}$ and $\mathrm{B}$, respectively. The sum of the nitrogen-containing compounds in the solid and liquid phases was taken as the initial degradable nitrogen, expressed as $\mathrm{NH}_{3}$, and the masses in lysimeters $\mathrm{A}$ and $\mathrm{B}$ were $3.1 \mathrm{~kg} / \mathrm{m}^{3}$ and $2.6 \mathrm{~kg} / \mathrm{m}^{3}$, respectively. The temperature was recorded in the monitoring data. Because oxygen was continuously supplied, the oxygen concentration was considered sufficient, and the volume fraction was calculated as $20 \%$. The carbon to nitrogen ratio was calculated according to the initial solid phase carbon and nitrogen values. The carbon to nitrogen ratios of both lysimeters were set at 15. The values of other reaction rate constants are shown (Table 2) [15-21].

Table 2. Biological parameters for simulation.

\begin{tabular}{ccc}
\hline Parameter & Symbol & Value (Day $^{-1}$ ) \\
\hline First order aerobic hydrolysis constant & $k_{h}$ & 0.1 \\
\hline First order SND constant & $k_{N}$ & 0.2 \\
\hline Microbial decay rate constant & $k_{d}$ & 1.0 \\
\hline
\end{tabular}

Here, the simulation parameters of the second group of experiments were different from those of the first group. This was caused mainly by the complexity of the initial degradable organic components, but the rate constant ratio within the two lysimeters was roughly a double relationship, and it is reasonable in a sense.

\subsubsection{Results and Discussion}

The temperature of the lysimeters showed annual fluctuations with peak-like profiles. The minimum, average, and maximum ambient temperatures were $-2.0,16.7$, and $37.0^{\circ} \mathrm{C}$, respectively. Within 300 days, the SDC degraded rapidly and reached a very low concentration, after which it continued to slowly decrease. During the first 100 days, the SDC degraded especially quickly due to suitable temperatures and the high concentration of organic matter. Due to a drop in the ambient temperature, the microbial activity was inhibited, and the degradation slowed between 100 and 200 days. After 200 days, the temperature rose, and the degradation rate once again increased. After 400 days, the SDC concentration was very low and the degradation was slow, but with the continuous oxygen supply the SDC continued to decrease. There was no significant difference in the degradation rates of the two lysimeters (Figure 7). 


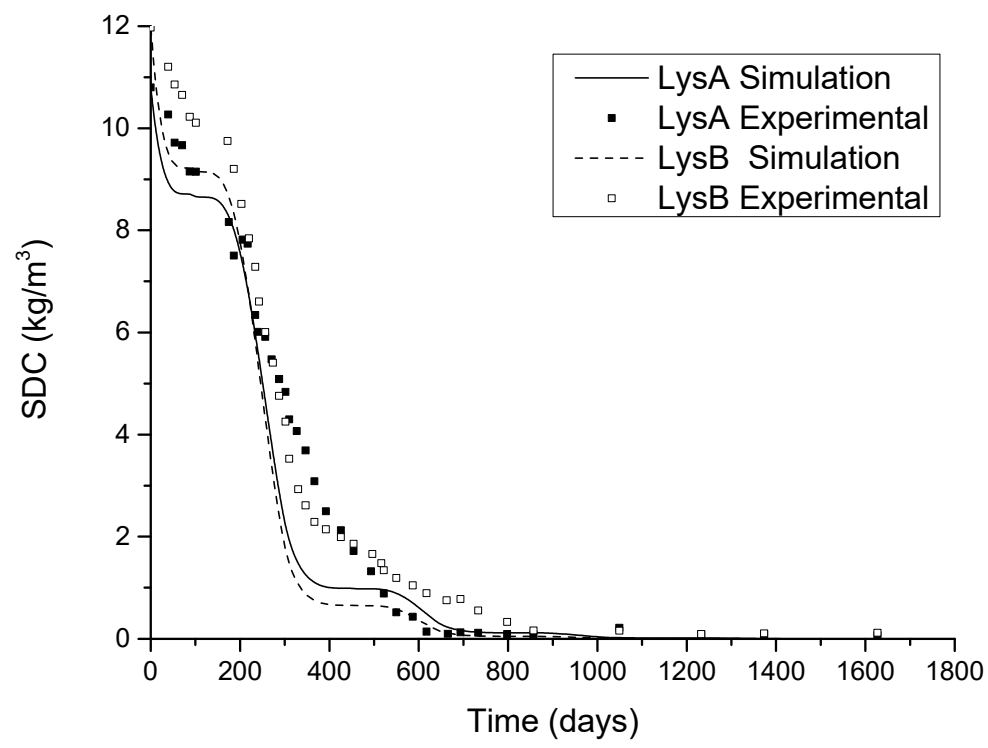

Figure 7. Time profiles of SDC degradation (experimental data cited in [37]).

The concentration of ammonia nitrogen could be seen to drop rapidly within 300 days, after which it slowly decreased. From days 100 to 200, the degradation rate slowed due to the low temperatures. After 200 days, the temperature increased, and the degradation rate accelerated. After 400 days, the degradation rate also decreased due to the low concentration of ammonia nitrogen. There was no significant difference in the degradation rates of the two lysimeters (Figure 8).

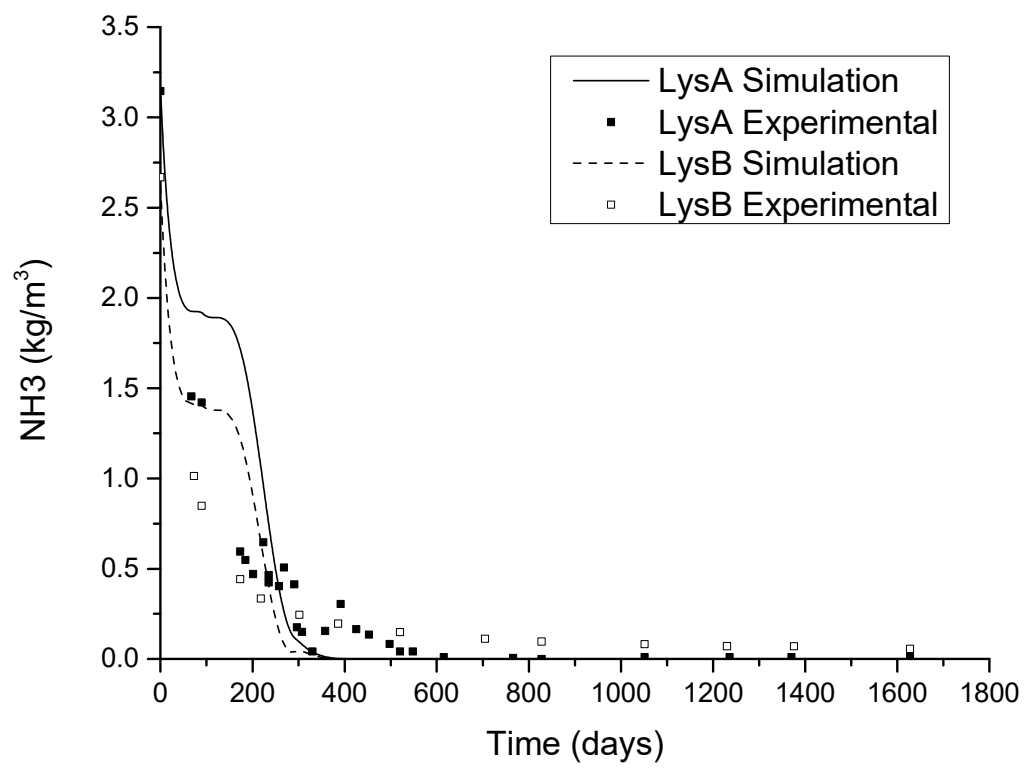

Figure 8. Time profiles of $\mathrm{NH}_{3}$ degradation (experimental data cited in [37]).

\section{Conclusions}

The degradable components of MSW can be divided into five categories, namely RDC, SDC, total sugars, fats, and proteins; and each can be used as a restrictive substrate. This classification method is conducive to the study of changes in chemical composition and the quality of MSW.

According to the law of conservation of electron charge and mass, aerobic hydrolysis of organics and synchronous nitrification and denitrification stoichiometric equations were established. These two types of reactions can explain the evolution of carbon and nitrogen 
in the degradable materials in MSW and help understand the interaction between carbon and nitrogen metabolism.

A set of aerobic degradation kinetic equations were established using first-order kinetic equations. These equations accounted for the influence of four factors, namely temperature, water content, oxygen concentration, and initial carbon-nitrogen ratio, on the biochemical reactions while also accounting for the heat release. The kinetic equation can be used to simulate the degradation rates of waste under different conditions.

The simulation results of the model can reflect the trend of test data as a whole. The model accurately reflected the changes of various substances under different degradation conditions and agreed with the experiment studying the different morphological transformations of carbon and nitrogen. SDC and ammonia nitrogen were rapidly degraded and reached very low levels in the early stages under aerobic conditions but then slowly decreased. This indicated that oxygen aeration has a significant effect on the degradation of aged waste, with degradation rates only slowing when SDC was nearly depleted.

This model can be further combined with the multi-field coupling model to analyze the process of accelerated degradation due to oxygenation in landfills.

Author Contributions: Conceptualization, Y.C. and L.Z.; methodology, D.X. and W.X.; software, D.X. and W.X.; validation, D.X.; formal analysis, D.X.; data curation, D.X.; writing-original draft preparation, D.X.; writing-review and editing, Y.C., W.X. and L.Z. All authors have read and agreed to the published version of the manuscript.

Funding: This research was funded by "the National Natural Science Foundation of China, grant number 51988101 and 51508504" and "the National Basic Research Program of China, grant number 2012CB719806".

Institutional Review Board Statement: Not applicable.

Informed Consent Statement: Not applicable.

Data Availability Statement: Not applicable.

Conflicts of Interest: The authors declare no conflict of interest.

\section{References}

1. Zaharioiu, A.; Bucura, F.; Ionete, E.I.; Ionete, R.E.; Ebrasu, D.; Sandru, C.; Marin, F.; Oancea, S.; Niculescu, V.; Miricioiu, M.G.; et al. Thermochemical Decomposition of Sewage Sludge-An Eco-Friendly Solution for a Sustainable Energy Future by Using Wastes. Rev. Chim. 2020, 71, 171-181. [CrossRef]

2. Bilgili, M.S.; Demir, A.; Ozkaya, B. Quality and quantity of leachate in aerobic pilot-scale landfills. Environ. Manag. 2006, 38, 189-196. [CrossRef]

3. Rendra, S.; Warith, M.A.; Fernandes, L. Degradation of municipal solid waste in aerobic bioreactor landfills. Environ. Technol. 2007, 28, 609-620. [CrossRef]

4. Jun, D.; Zhao, Y.; Henry, R.K.; Mei, H. Impacts of aeration and active sludge addition on leachate recirculation bioreactor. J. Hazard. Mater. 2007, 147, 240-248. [CrossRef] [PubMed]

5. Erses, A.S.; Onay, T.T.; Yenigun, O. Comparison of aerobic and anaerobic degradation of municipal solid waste in bioreactor landfills. Bioresour. Technol. 2008, 99, 5418-5426. [CrossRef] [PubMed]

6. Berge, N.D.; Reinhart, D.R.; Batarseh, E.S. An assessment of bioreactor landfill costs and benefits. Waste Manag. 2009, 29, 1558-1567. [CrossRef]

7. Raga, R.; Cossu, R. Landfill aeration in the framework of a reclamation project in Northern Italy. Waste Manag. 2014, 34, 683-691. [CrossRef] [PubMed]

8. Ni, Z.; Liu, J.; Girotto, F.; Cossu, R.; Qi, G. Targeted modification of organic components of municipal solid waste by short-term pre-aeration and its enhancement on anaerobic degradation in simulated landfill bioreactors. Bioresour. Technol. 2016, 216, 250-259. [CrossRef] [PubMed]

9. Hrad, M.; Huber-Humer, M. Performance and completion assessment of an in-situ aerated municipal solid waste landfill-Final scientific docu- mentation of an Austrian case study. Waste Manag. 2016, 63, 397-409. [CrossRef] [PubMed]

10. Iordache, M.; Iordache, A.M.; Sandru, C.; Voica, C.; Zgavarogea, R.; Miricioiu, M.G.; Ionete, R.E. Assessment of Heavy Metals Pollution in Sediments from Reservoirs of the Olt River as Tool for Environmental Risk Management. Rev. Chim. 2019, 70, 4153-4162.

11. Read, A.D.; Hudgins, M.; Phillips, P. Perpetual landfilling through aeration of the waste mass; lessons from test cells in Georgia (USA). Waste Manag. 2001, 21, 617-629. [CrossRef] 
12. Cossu, R.; Raga, R.; Rossetti, D. The PAF model: An integrated approach for landfill sustainability. Waste Manag. 2003, 23, 37-44. [CrossRef]

13. Cossu, R. The sustainable landfilling concept. In Proceedings of the Sardinia 2005, 10th International Waste Management and Landfill Symposium, CISA, Liari, Italy, 7 October 2005.

14. Ritzkowski, M.; Heyer, K.-U.; Stegmann, R. Fundamental processes and implications during in situ aeration of old landfills. Waste Manag. 2006, 26, 356-372. [CrossRef] [PubMed]

15. Das, K.; Keener, H.M. Numerical model for the dynamic simulation of a large scale composting system. Trans. ASAE 1997, 40, 1179-1189. [CrossRef]

16. Higgins, C.W.; Walker, L.P. Validation of a new model for aerobic organic solids decomposition: Simulations with substrate specific kinetics. Process. Biochem. 2001, 36, 875-884. [CrossRef]

17. Vavilin, V.A.; Rytov, S.V.; Lokshina, L.Y.; Pavlostathis, S.G.; Barlaz, M.A. Distributed model of solid waste anaerobic digestion: Effects of leachate recirculation and $\mathrm{pH}$ adjustment. Biotechnol. Bioeng. 2003, 81, 66-73. [CrossRef]

18. Sole-Mauri, F.; Illa, J.; Magrí, A.; Prenafeta-Boldú, F.X.; Flotats, X. An integrated biochemical and physical model for the composting process. Bioresour. Technol. 2007, 98, 3278-3293. [CrossRef]

19. Slezak, R.; Krzystek, L.; Ledakowicz, S. Simulation of aerobic landfill in laboratory scale lysimeters-effect of aeration rate. Chem. Pap. 2010, 64, 223-229. [CrossRef]

20. Guo, R.; Li, G.; Jiang, T.; Schuchardt, F.; Chen, T.; Zhao, Y.; Shen, Y. Effect of aeration rate, C/N ratio and moisture content on the stability and maturity of compost. Bioresour. Technol. 2012, 112, 171-178. [CrossRef]

21. Petric, I.; Mustafic, N. Dynamic modeling the composting process of the mixture of poultry manure and wheat straw. J. Environ. Manag. 2015, 161, 392-401. [CrossRef]

22. Kaiser, J. Modelling composting as a microbial ecosystem: A simulation approach. Ecol. Model. 1996, 91, 25-37. [CrossRef]

23. Tremier, A.; de Guardia, A.; Massiani, C.; Paul, E.; Martel, J.L. A respirometric method for characterising the organic composition and biodegradation kinetics and the temperature influence on the biodegradation kinetics, for a mixture of sludge and bulking agent to be co-composted. Bioresour. Technol. 2005, 96, 169-180. [CrossRef] [PubMed]

24. Qin, X.; Huang, G.; Zeng, G.; Chakma, A.; Xi, B. A Fuzzy Composting Process Model. J. Air Waste Manag. Assoc. 2007, 57, 535-550. [CrossRef]

25. Zhang, Y.; Lashermes, G.; Houot, S.; Doublet, J.; Steyer, J.P.; Zhu, Y.G.; Barriuso, E.; Garnier, P. Modelling of organic matter dynamics during the composting process. Waste Manag. 2012, 32, 19-30. [CrossRef] [PubMed]

26. Fytanidis, D.K.; Voudrias, E.A. Numerical simulation of landfill aeration using computational fluid dynamics. Waste Manag. 2014, 34, 804-816. [CrossRef] [PubMed]

27. Adhikari, B.K.; Barrington, S.; Martinez, J.; King, S. Characterization of food waste and bulking agent for composting. Waste Manag. 2008, 28, 795-804. [CrossRef]

28. Chang, J.I.; Hsu, T.E. Effect of compositions on food waste composting. Bioresour. Technol. 2008, 99, 8068-8074. [CrossRef]

29. Kumar, M.; Ou, Y.L.; Lin, J.G. Co-composting of green waste and food waste at low C/N ratio. Waste Manag. 2010, 30, 602-609. [CrossRef] [PubMed]

30. Ma, J.; Liu, L.; Ge, S.; Xue, Q.; Li, J.-S.; Wan, Y.; Hui, X. Coupling model of aerobic waste degradation considering temperature, initial moisture content and air injection volume. Waste Manag. Res. 2018, 36, 277-287. [CrossRef]

31. Ma, J.; Lei, L.; Xue, Q.; Yang, Y.; Zhang, Y.; Fei, X. A systematic assessment of aeration rate effect on aerobic degradation of municipal solid waste based on leachate chemical oxygen demand removal. Chemosphere 2020, 263, 128218. [CrossRef]

32. Jacobs, J.; Scharff, H.; Van Arkel, F.; De Gier, C.W. Odour reduction by aeration of landfills: Experience, operation and costs. In Proceedings of the 9th International Waste Management and Landfill Symposium, Cagliari, Italy, 6-10 October 2003.

33. Hantsch, S.; Michalzik, B.; Bilitewski, B. Different intensities of aeration and their effect on contaminant emission via the leachate pathway from old landfill waste-A laboratory scale study. In Proceedings of the 9th International Waste Management and Landfill Symposium, Cagliari, Italy, 6-10 October 2003.

34. Zieleniewska-Jastrzebska, A.; Krzystek, L.; Ledakowicz, S. Aerobic stabilization of old landfills-Experimental simulation in lysimeters. In Management of Pollutant Emission from Landfills and Sludge; Pawlowska, M., Pawlowski, L., Eds.; Taylor \& Francis: Kazimierz Dolny, Poland, 2007; pp. 55-62.

35. Prantl, R.; Tesar, M.; Huber-Humer, M.; Lechner, P. Changes in carbon and nitrogen pool during in-situ aeration of old landfills under varying conditions. Waste Manag. 2006, 26, 373-380. [CrossRef]

36. Raga, R.; Cossu, R. Bioreactor tests preliminary to landfill in situ aeration: A case study. Waste Manag. 2013, 33, 871-880. [CrossRef]

37. Wu, C.; Shimaoka, T.; Nakayama, H.; Komiya, T.; Chai, X. Stimulation of waste decomposition in an old landfill by air injection. Bioresour. Technol. 2016, 222, 66-74. [CrossRef]

38. McCarty, P.L. Stoichiometry of biological reactions. Progr. Water Technol. 1975, 7, 157-172.

39. Zhou, S.Q. Biochemical reaction mechanism of landfill leachate simultaneous aerobic and anaerobic biological treatment. $J$. Shihezi Univ. Nat. Sci. 2005, 23, 276-279.

40. Chen, Y. A fundamental theory of environmental geotechnics and its application. Chin. J. Geotech. Eng. 2014, 36, 1-46. 
41. Xiao, D.; Xu, W.; Zhan, L.; Chen, Y. A model for aerobic biochemical degradation of municipal solid waste. In Environmental Science and Engineering, Proceedings of the 8th International Congress on Environmental Geotechnics-Towards a Sustainable Geoenvironment, Hangzhou, China, 11 October 2018; Springer: Singapore, 2019; Volume 3, pp. 263-271.

42. Hoover, S.R.; Porges, N. Assimilation of dairy wastes by activated sludge: II. the equation of synthesis and rate of oxygen utilization. Sew. Ind. Waste. 1952, 24, 306-312.

43. Symons, J.M.; Mckinney, R.E. The biochemistry of nitrogen in the synthesis of ac-tivated sludge. Sew. Ind. Wastes 1958, 30, 874-890.

44. Li, K.; Chen, Y.; Xu, W.; Zhan, L.; Ling, D.; Ke, H.; Hu, J.; Li, J. A thermo-hydro-mechanical-biochemical coupled model for landfilled municipal solid waste. Comput. Geotech. 2021, 134, 104090. [CrossRef]

45. Haug, R.T. The Practical Handbook of Compost Engineering; Routledge: Boca Raton, FL, USA, 1993.

46. Rosso, L.; Lobry, J.R.; Flandrois, J.P. An unexpected correlation between cardinal temperatures of microbial growth highlighted by a new model. J. Theor. Biol. 1993, 162, 447-463. [CrossRef]

47. Wang, X.; Lu, X.; Li, F.; Yang, G.; Yang, G. Effects of Temperature and Carbon-Nitrogen (C/N) Ratio on the Performance of Anaerobic Co-Digestion of Dairy Manure, Chicken Manure and Rice Straw: Focusing on Ammonia Inhibition. PLoS ONE 2014, 9 , e97265. [CrossRef] [PubMed] 